\title{
HIGH CYCLE FATIGUE PERFORMANCE OF TI6AL4V(ELI) SPECIMENS PRODUCED WITH INHERENT LASER POWDER BED FUSION SURFACE ROUGHNESS
}

\author{
H. Miya ${ }^{1 *}$, W. du Preez ${ }^{1} \&$ L. Monaheng ${ }^{1}$
}

\section{ARTICLE INFO}

\begin{abstract}
Article details
Presented at the $22^{\text {nd }}$ Annual International Conference of the Rapid Product Development Association of South Africa (RAPDASA), held from 3-5 November 2021 in Pretoria, South Africa.
\end{abstract}

Available online $\quad 29$ Nov 2021

Contact details

* Corresponding author hmiya@cut.ac.za

Author affiliations

1 Dept. of Mechanical and

Mechatronics Engineering, Central University of Technology, South Africa

\section{ORCID® identifiers}

H. Miya

https://orcid.org/0000-0002-7804-0681

W. du Preez

https://orcid.org/0000-0001-9935-7330

L. Monaheng

http://orcid.org/0000-0002-2263-3162

DOI

http://dx.doi.org/10.7166/32-3-2659

\section{ABSTRACT}

This study investigated how surface defects affect the fatigue performance of laser powder bed fusion (LPBF) Ti6Al4V(ELI) test specimens in as-built surface roughness and heat-treated conditions. Tensile and fatigue specimens were built in three orthogonal directions for testing. Fatigue testing was carried out to determine the maximum stress at which a runout number of 5 million cycles to failure could be achieved. Fractured specimens were analysed and compared for crack initiation and propagation characteristics using scanning electron microscopy. Conclusions were drawn on the possibility of producing Ti6Al4V(ELI) aircraft components through LPBF.

\section{OPSOMMING}

In hierdie studie is die effek van oppervlakdefekte op die vermoeidheidsgedrag van laser poeierbedfusie (LPBF) Ti6Al4V(ELI) toetsmonsters, met inherente oppervlakrofheid, in die soos-gebou en hittebehandelde toestande ondersoek. Trektoets- en vermoeidheidstoetsmonsters is gebou in drie ortogonale rigtings. Vermoeidheidstoetsing is uitgevoer om die maksimum spanning waarby 'n uitloopgetal van vyf miljoen siklusse voor faling bereik word te bepaal. Die breekvlakke van toetsmonsters is met behulp van skandeerelektronmikroskopie ondersoek om kraakoorsprong- en kraakvoortplantingseienskappe te verkry. Gevolgtrekkings oor die moontlikheid om Ti6Al4V(ELI) lugvaartkomponente met LPBF te vervaardig, is gemaak.

\section{INTRODUCTION}

The laser powder bed fusion (LPBF) process has gained acceptance in the aerospace industry because it has the advantage of producing complex-shaped parts with little raw material wastage [1]. However, the parts produced by this process might contain defects that reduce their fatigue life [2,3]. Therefore, the mechanical performance of aircraft parts produced through LPBF must be determined before they can be used in critical load-bearing applications [4].

The $\alpha+\beta$ alloy Ti6Al4V is commonly used in producing structural aircraft components in the aircraft industry [5]. Ti6Al4V alloy contributes to saving weight in structural aircraft components owing to its high specific strength. The microstructure of this alloy can be tailored to the required mechanical properties, such as high tensile strength and ductility, by optimising the LPBF process and the post-process heat treatment [6].

The high cycle fatigue (HCF) properties of LPBF parts are affected by defects such as residual stresses, lack of fusion, and porosity. These defects are inherent in the LPBF process, and have already been investigated $[2,5,7]$. However, the effect of surface roughness on HCF performance still needs to be explored. 
Surface roughness impacts negatively on the fatigue life of Ti6Al4V parts produced through LPBF $[8,9]$. It is dependent on the LPBF machine parameters, such as the thickness of the build layer, the allowable powder size distribution, and the laser energy [8]. Furthermore, the LPBF mechanisms, such as powder distribution onto the building substrate (recoating), build orientation, which impacts the staircase effect (visible layer marks on the part caused by an offset between the layers when forming a round or curve, creating a rough surface), and lack of fusion of the powder particles onto the as-built surface, directly affect the surface roughness of the end product [9]. Surface topography features consist of sharp multiple radii of curvature that act as local notches and create local stress concentration sites, which may lead to crack initiation at the as-built surface [10].

Creating a smooth LPBF part surface implies additional costs, because specialised machining or polishing must be implemented - and it might even be impossible to do with complex-shaped components. This should be avoided to retain the economic advantage of using LPBF to produce complex-shaped aircraft structural components [7].

Kahlin et al. [11] reported on the fatigue behaviour of electron beam melting (EBM) and selective laser melting (SLM) Ti6Al4V. By comparing the fatigue strength of as-built and machined specimens, it was found that surface roughness contributed most significantly to the fatigue properties and reduced the fatigue limit by approximately $45 \%$.

The purpose of the current study was to investigate the effect of inherent LPBF surface roughness on the fatigue performance of net-shaped Ti6Al4V(ELI) test specimens.

\section{MATERIAL AND EXPERIMENTAL PROCEDURE}

\subsection{Specimen preparation}

A total of $21 \mathrm{HCF}$ LPBF Ti6Al4V(ELI) cylindrical test specimens were manufactured using the EOSINT M280 machine equipped with a $200 \mathrm{~W}$ ytterbium fibre laser, a beam diameter of $80 \mu \mathrm{m}$, a scanning speed of 1400 $\mathrm{mm} / \mathrm{s}$, a layer thickness of $30 \mu \mathrm{m}, 40^{\circ} \mathrm{C}$ bed temperature, a back-and-forth scanning pattern, and hatch spacing of $100 \mu \mathrm{m}$. These specimens were built in three orthogonal directions $(X, Y$, and $Z)$ as shown in Figure 1, with seven specimens for each orientation. $T$ mbnbbhhese specimens were built to net-shape according to the ASTM E466 standard for fatigue testing [12]. To confirm the build quality, nine cylindrical tensile test specimens were built on the same platform as the HCF test specimens, and with the same orientations.

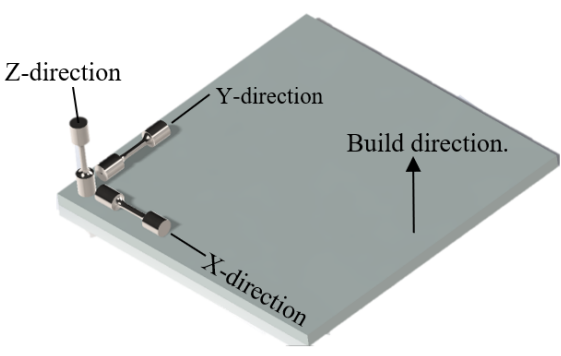

(a)

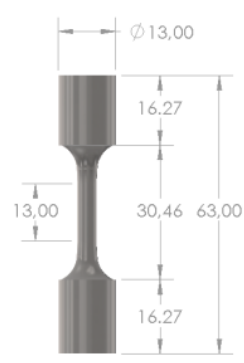

(b)

Figure 1: Illustration of LPBF Ti6Al4V(ELI) test specimens: a) test specimens on a base plate; $b$ ) test specimen dimensions in millimeters

\subsection{Post-process heat treatment of test specimens}

Both the HCF and the tensile Ti6Al4V(ELI) LPBF test specimens were subjected to a dual-stage heat treatment. To reduce the residual stress inherent in the LPBF process, the heat treatment was performed at $650{ }^{\circ} \mathrm{C}$ for a soaking period of three hours in a vacuum furnace, followed by furnace cooling to room temperature. This was followed by high-temperature annealing (HTA) at $950{ }^{\circ} \mathrm{C}$ for a soaking period of three hours and furnace cooling, to improve the fatigue properties of the test specimens [10].

\subsection{Micro-computed tomography}

Micro-computed tomography (micro-CT) analyses were used as a quality-control measure for the LPBF process. Representative specimens were analysed using a micro-focus X-ray machine type NIKON XTH 225 
ST. It was set to a current of $200 \mu \mathrm{A}$, an acceleration potential of $185 \mathrm{kV}$, an exposure time of 4 four seconds per projection, and 2000 projections per specimen.

\subsection{Tensile testing}

The tensile testing of the specimens was performed using an Instron 1342 servo-hydraulic testing machine and done according to the ASTM E8 standard for testing metals. A total of nine specimens were tested (three per direction; X1-X3, Y1-Y3, and Z1-Z3).

\subsection{Tension-tension fatigue testing}

The high-cycle axial force-controlled fatigue testing of the specimens was performed under the test criteria in Table 1.

Table 1. Test criteria for axial force-controlled fatigue testing

\begin{tabular}{|c|c|}
\hline Testing standard & ASTM E 466 - 15 and ISO 1099 \\
\hline $\begin{array}{c}\text { Testing } \\
\text { equipment }\end{array}$ & $\begin{array}{c}50 \mathrm{kN} \text { Instron 1432, axial, servo- } \\
\text { hydraulic }\end{array}$ \\
\hline R-ratio & 0.1 \\
\hline Control mode & Stress control mode \\
\hline Frequency & $10 \mathrm{~Hz}$ \\
\hline Temperature & $20 \pm 2{ }^{\circ} \mathrm{C}$ \\
\hline Run out & 5000000 \\
\hline
\end{tabular}

\subsection{Fractography}

The fractured surfaces of the tensile and HCF LPBF Ti6Al4V(ELI) test specimens were investigated in a JOEL JSM-7800F scanning electron microscope (SEM). The imaging was done using the secondary electron imaging (SEI) mode of the SEM at $10-20 \mathrm{kV}$ for working distances of up to $50 \mathrm{~mm}$.

\section{RESULTS AND DISCUSSION}

\subsection{Micro-computed tomography results}

A scanning resolution of $8.2 \mu \mathrm{m}$ was used to analyse the gauge length area of the representative test specimens. All scans were performed to evaluate the material density and the level of porosity, which was found to be below $0.01 \%$. The porosity information is presented in Table 2 .

Table 2: Porosity information of Ti6Al4V(ELI) test specimens produced by LPBF

\begin{tabular}{|l|l|}
\hline Specimen designation & Porosity (\%) \\
\hline $\mathrm{X} 1$ & 0.0029 \\
\hline $\mathrm{Y} 1$ & 0.0033 \\
\hline $\mathrm{Z} 1$ & 0.0011 \\
\hline
\end{tabular}

\subsection{Tensile properties of Ti6Al4V(ELI) test specimens produced through LPBF}

The tensile test results for the X-, Y-, and Z-direction test specimens are given in Table 3.

The tensile properties in Table 3 complied with the specified properties in ASTM F3001 - 14 for additive manufacturing Ti6Al4V(ELI) with powder bed fusion [13].

The specimens in the $\mathrm{X}$ - and $\mathrm{Y}$-directions exhibited similar tensile properties, with the tensile stress at yield ranging from $852 \mathrm{MPa}$ on the $\mathrm{X} 2$ specimen to $863 \mathrm{MPa}$ on the $\mathrm{Y} 1$ specimen. This showed no significant difference between the X- and Y-direction specimens. However, there was anisotropy when they were compared with the Z-direction specimens, with the maximum tensile stress at a yield at $781 \mathrm{MPa}$ for the Z3 specimen. This is common for LPBF-built parts owing to the layer-by-layer building, compared with the direction of the tensile force during tension testing $[3,12]$. In general, the tensile properties for all X-, $Y$ , and Z-specimens meet the minimum requirements of ASTM F3001 - 14. 
Table 3: Tensile test results for X-, Y-, and Z-direction LPBF Ti6Al4V(ELI) test specimens

\begin{tabular}{|c|c|c|c|c|c|}
\hline $\begin{array}{c}\text { Specimen } \\
\text { Designation }\end{array}$ & $\begin{array}{c}\text { Area } \\
\left(\mathrm{mm}^{\wedge} \mathbf{2}\right)\end{array}$ & $\begin{array}{c}\text { Tensile Stress } \\
\text { at Yield } \\
\text { (Offset } 0.2 \% \text { ) } \\
\text { (MPa) }\end{array}$ & $\begin{array}{c}\text { Modulus } \\
\text { of } \\
\text { Elasticity } \\
(\mathrm{GPa})\end{array}$ & $\begin{array}{l}\text { Ultimate } \\
\text { Tensile } \\
\text { Strength } \\
\text { (MPa) }\end{array}$ & $\begin{array}{c}\text { Percentage } \\
\text { Elongation } \\
(\%)\end{array}$ \\
\hline \multicolumn{6}{|c|}{ ASTM F $3001-14$} \\
\hline- & $\begin{array}{l}<4.75 \mathrm{~mm} \\
\text { diameter }\end{array}$ & 795 & - & 860 & 10 \\
\hline \multicolumn{6}{|c|}{ This study } \\
\hline $\mathrm{X} 1$ & 13.85 & 860.42 & 116.3 & 948.13 & 16.50 \\
\hline $\mathrm{X} 2$ & 13.85 & 852.44 & 113.9 & 939.65 & 15.50 \\
\hline $\mathrm{X} 3$ & 13.85 & 853.73 & 115.0 & 941.53 & 15.05 \\
\hline Y1 & 13.85 & 863.94 & 118.1 & 947.64 & 13.25 \\
\hline $\mathrm{Y} 2$ & 13.85 & 860.75 & 120.8 & 943.50 & 14.70 \\
\hline Y3 & 13.85 & 856.71 & 114.6 & 941.14 & 15.05 \\
\hline Z1 & 14.32 & 774.78 & 110.0 & 888.52 & 15.75 \\
\hline $\mathrm{Z} 2$ & 14.25 & 780.48 & 109.5 & 894.81 & 15.60 \\
\hline Z3 & 14.25 & 781.33 & 108.5 & 891.61 & 16.15 \\
\hline Mean & 13.99 & 831.62 & 114.08 & 926.28 & 15.28 \\
\hline $\begin{array}{c}\text { Coefficient of } \\
\text { variation }\end{array}$ & 1.501 & 4.781 & 3.620 & 2.825 & 6.217 \\
\hline Range & 0.47 & 89.16 & 12.3 & 59.61 & 3.25 \\
\hline Standard deviation & 0.21 & 39.76 & 4.13 & 26.17 & 0.95 \\
\hline Minimum & 13.85 & 774.78 & 108.5 & 888.52 & 13.25 \\
\hline Maximum & 14.32 & 863.94 & 120.8 & 948.13 & 16.50 \\
\hline Median & 13.85 & 853.73 & 114.6 & 941.14 & 15.50 \\
\hline
\end{tabular}

\subsection{Fatigue properties of Ti6Al4V(ELI) test specimens produced through LPBF}

The HCF test results are given in Table 4 for the Z-specimens, Table 5 for the X-specimens, and Table 6 for the $Y$ - specimens.

Table 4: Fatigue test results for Z-direction LPBF Ti6Al4V(ELI) test specimens

\begin{tabular}{|l|l|l|}
\hline $\begin{array}{l}\text { Specimen } \\
\text { designation }\end{array}$ & $\begin{array}{l}\text { Maximum stress } \\
(\mathrm{MPa})\end{array}$ & $\begin{array}{l}\text { Number of cycles to } \\
\text { fatigue failure }\left(\mathbf{N}_{\mathbf{f}}\right)\end{array}$ \\
\hline $\mathrm{Z8}$ & 225 & 5000000 \\
\hline $\mathrm{Z9}$ & 250 & 730494 \\
\hline $\mathrm{Z7})$ & 270 & 370439 \\
\hline $\mathrm{Z10}$ & 300 & 483996 \\
\hline $\mathrm{Z6}$ & 360 & 122595 \\
\hline $\mathrm{Z5}$ & 418 & 61584 \\
\hline $\mathrm{Z4}$ & 450 & 50142 \\
\hline
\end{tabular}

Table 5. Fatigue test results for X-direction LPBF Ti6Al4V(ELI) test specimens

\begin{tabular}{|l|l|l|}
\hline $\begin{array}{l}\text { Specimen } \\
\text { designation }\end{array}$ & $\begin{array}{l}\text { Maximum stress } \\
(\mathrm{MPa})\end{array}$ & $\begin{array}{l}\text { Number of cycles to } \\
\left.\text { fatigue failure } \mathbf{( N}_{\mathbf{f}}\right)\end{array}$ \\
\hline $\mathrm{X} 8$ & 190 & 5000000 \\
\hline $\mathrm{X} 10$ & 200 & 1153581 \\
\hline $\mathrm{X} 7$ & 210 & 893273 \\
\hline $\mathrm{X} 6$ & 230 & 513876 \\
\hline $\mathrm{X} 9$ & 270 & 346930 \\
\hline $\mathrm{X} 5$ & 300 & 218190 \\
\hline $\mathrm{X} 4$ & 360 & 147027 \\
\hline
\end{tabular}

Table 6. Fatigue test results for Y-direction LPBF Ti6Al4V(ELI) test specimens

\begin{tabular}{|l|l|l|}
\hline $\begin{array}{l}\text { Specimen } \\
\text { designation }\end{array}$ & $\begin{array}{l}\text { Maximum } \\
\text { stress }(\mathrm{MPa})\end{array}$ & $\begin{array}{l}\text { Number of cycles to } \\
\left.\text { fatigue failure } \mathbf{( N}_{\mathbf{f}}\right)\end{array}$ \\
\hline Y7 & 190 & 5000000 \\
\hline Y10 & 200 & 1002143 \\
\hline Y6 & 230 & 598800 \\
\hline Y8 & 250 & 538903 \\
\hline Y9 & 270 & 434787 \\
\hline Y5 & 300 & 304007 \\
\hline Y4 & 360 & 132859 \\
\hline
\end{tabular}

The fatigue data of these specimens are presented in Figure 2. 


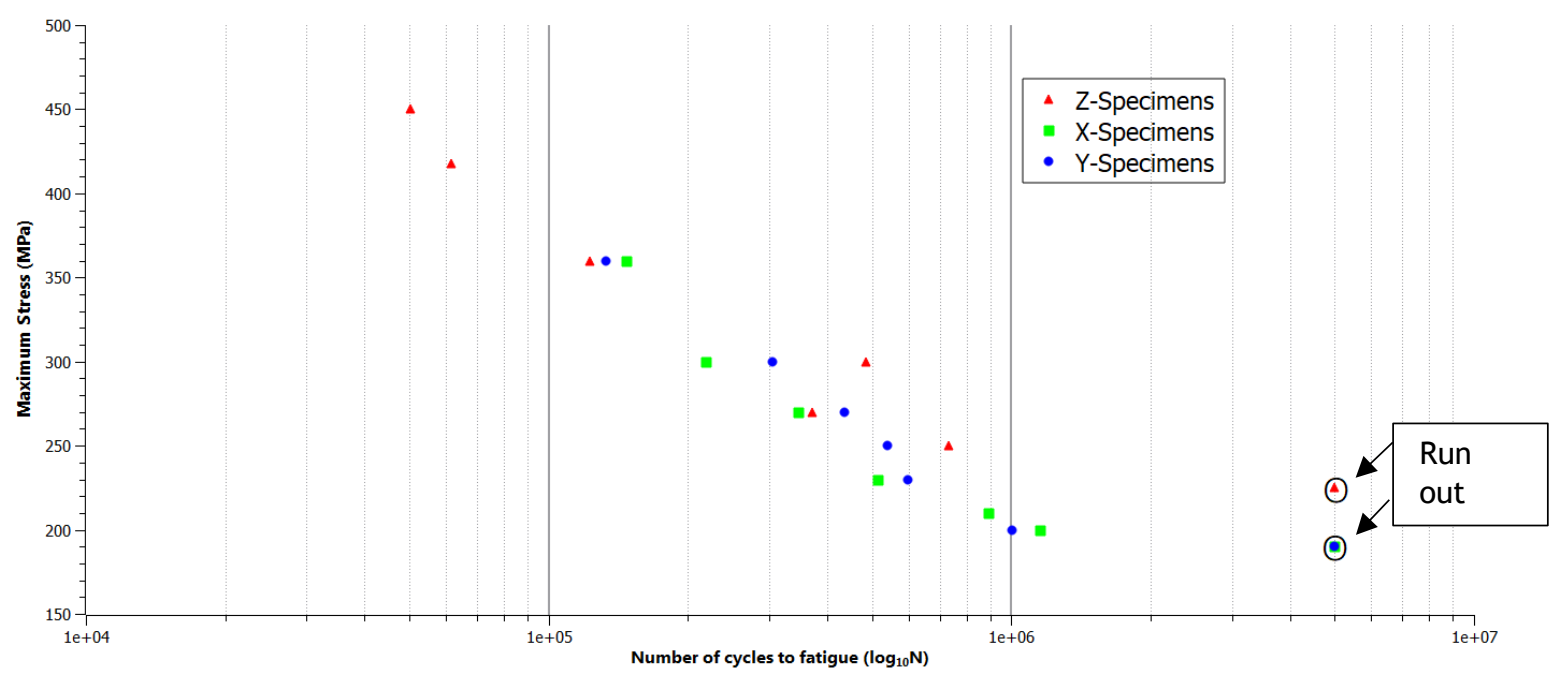

Figure 2: Fatigue life of Ti6Al4V(ELI) test specimens

These fatigue results showed characteristics similar to the curve profile for Ti6Al4V(ELI) observed by Malefane et al. [14] on machined test specimens. A comparison between the X-and Y-direction specimens showed no significant effect of the layer orientation on the fatigue performance. However, the fatigue performance of the Z-direction specimens differed significantly from that of the $X$ - and $Y$ direction specimens. The endurance limit of 5 million cycles was achieved at $225 \mathrm{MPa}$ for the Z-direction built specimens and $190 \mathrm{MPa}$ for both the $\mathrm{X}$ - and the $\mathrm{Y}$-direction specimens. This can be ascribed to the surface irregularities on the $\mathrm{X}$ - and $\mathrm{Y}$-direction specimens where the support structures were removed (see Figure 3)

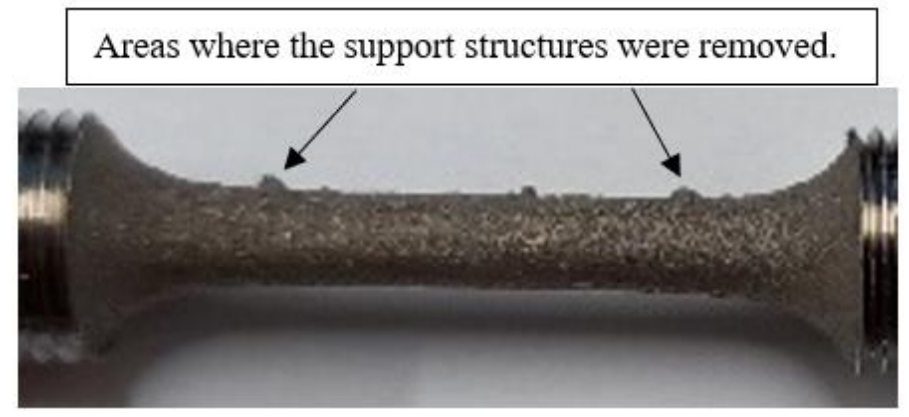

Figure 3: Gauge length of LPBF Ti6Al4V test specimen built in X-direction

In the study of Malefane et al. [14], the vertically built specimens showed a shorter fatigue life than the horizontal specimens owing to the effect of internal defects (entrapped sub-surface gas pores) that were inherent in the LPBF process. In the current study, specimens $X 8$ and $Y 7$ could reach an endurance limit of 5 million cycles at $190 \mathrm{MPa}$, while the Z8 specimen reached the limit at the maximum stress of $225 \mathrm{MPa}$. This implies that the surface irregularities had a major effect on the fatigue properties of LPBF Ti6Al4V(ELI) compared with the inherent internal defects. The surface irregularities on the specimens that endured the maximum stress until 5 million cycles were investigated and compared at the same magnification. Figure 4 shows these comparisons. 


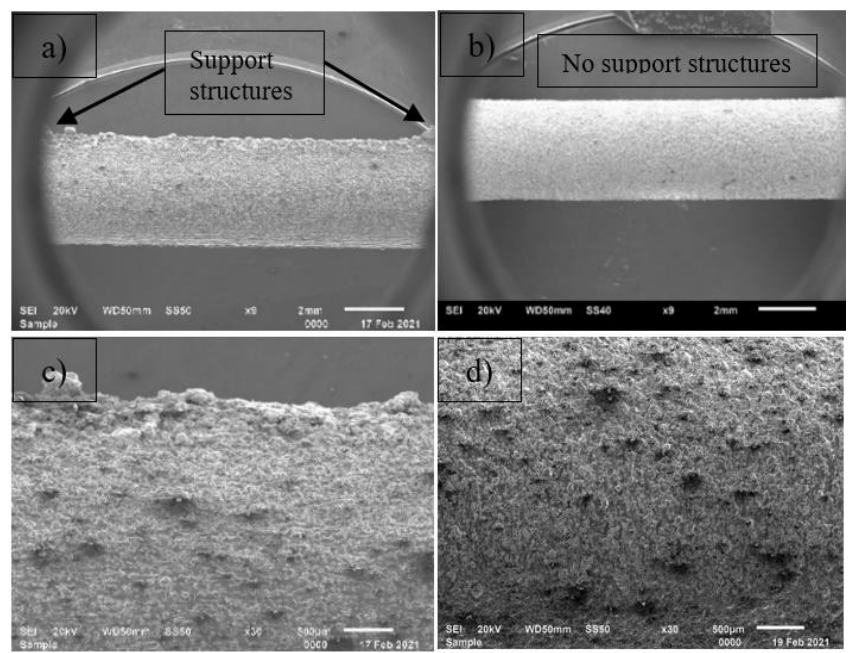

Figure 4: SEM SEI of Ti6Al4V(ELI) specimen gauge length: a) X8; b) Z8; c) high magnification of X8; d) high magnification of Z8

Figures $4 \mathrm{a}$ and $4 \mathrm{~b}$ show that the specimens built in the $\mathrm{X}$-direction (which was similar to the specimens built in the Y-direction) appeared to be rough on the gauge length area when compared with the specimens built in the Z-direction. This is an indication that the layer orientation has an effect on the surface roughness of the LPBF parts. Bhardwaj et al. [15] discovered that a decrease in surface roughness occurred when there was high heat flow in deposited layers, leading to the closure of pores and cracks induced during fabrication. Casalino et al. [16] also observed that the vertically built orientation yielded a lower surface roughness owing to the short scan lengths that led to a higher amount of heat flow into the previously solidified layers. The work on the current study corresponds with that of Casalino et al. [16], as shown by Figure 4.

Furthermore, the LPBF Ti6Al4V test specimens in other studies $[3,10]$ showed an inverse correlation between the maximum stress and the number of cycles to fatigue. This phenomenon was observed in this study, in which the $\mathrm{X}$ - and $\mathrm{Y}$-direction as-built specimens had increased the number of cycles to fatigue as the maximum applied stress was reduced. However, for the Z-direction specimens, specimen Z7 failed at $270 \mathrm{MPa}$ with 370439 cycles to failure, while Z10 failed at $300 \mathrm{MPa}$ with 483996 cycles to failure. The Z7 and Z10 specimens failed outside the gauge length, and can thus be considered outliers.

\subsection{Fractography of Ti6Al4V(ELI) test specimens produced through LPBF}

The fracture surfaces revealed three stages of fatigue fracture (crack initiation zone, propagation zone, and final fracture) that were also observed in other studies [8, 12, 13]. Chastand et al. [17] identified subsurface defects such as pores as the most critical type of defect influencing the fatigue properties of SLM Ti-6Al-4V. This was confirmed by Dallago et al. [18]. Large pores resulted in accelerated local plastic deformation that initiates crack propagation, thus affecting the fatigue life of LPBF Ti6AL4V specimens [14]. Figure 5 shows the fracture surface of the Z4 specimen that failed at 50142 cycles at the maximum stress of $450 \mathrm{MPa}$.

The crack was initiated in the circled area in Figure 5. It propagated towards the centre of the specimen, as indicated by the arrows. A magnified image of the crack initiation area in Figure 5 is presented in Figure 6a. An inclusion and a lack of fusion near the outer surface of the specimen were observed. Partially melted powder particles on the outer surface of the specimen were also observed. These features promote crack initiation, and are associated with surface defects because they are features that appear on the outer surface [17]. 




Figure 5: SEM SEI of fracture surface of Z4 specimen: a) stable crack propagation area; b) unstable crack propagation area; c) final fracture area

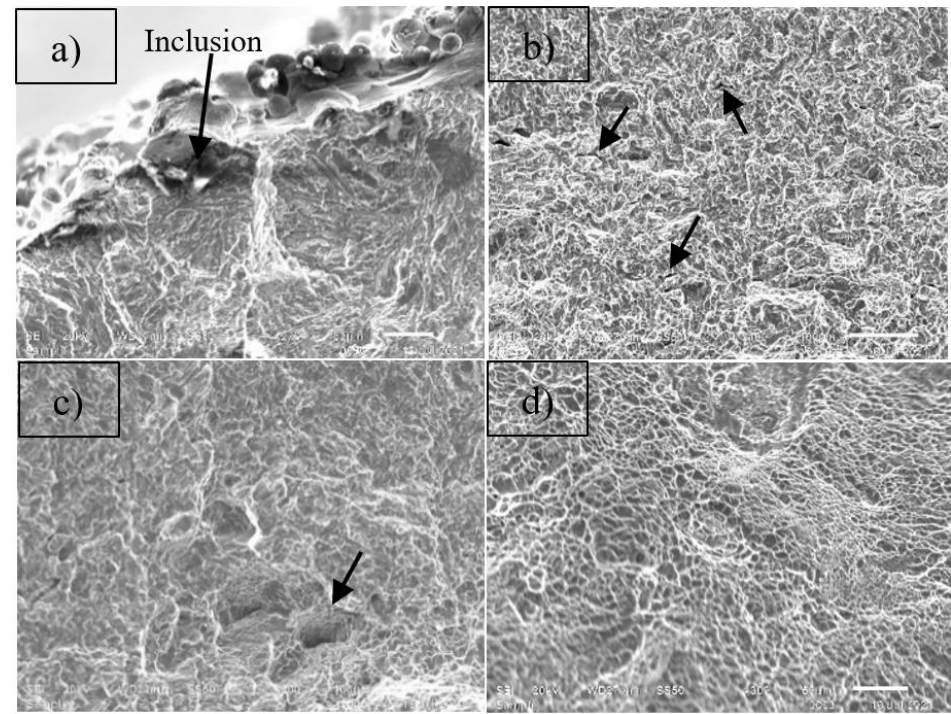

Figure 6: SEM SEI of high magnification areas of Figure 5: a) crack initiation; b) area A, showing slow crack propagation with micro cracks; c) area B, showing faster crack propagation with shallow dimples; d) area $C$, showing final fracture

Furthermore, Figure $6 \mathrm{~b}$, a higher magnification of the area labelled ' $A$ ' in Figure 5 , shows the characteristics of stable crack propagation with small areas of fatigue striations and tear ridges. The tear ridges started to appear on the area close to the initiation point, then disappeared in the middle of area $A$ in Figure 5. There were also micro-cracks (Figure 6b) leading to faster crack propagation in area B in Figure 5 (a higher magnification of area B is in Figure $6 \mathrm{c}$ ). The faster crack propagation was typified by connected microcracks forming a shallow dimple fracture mode that leads to the final fracture, which is fibrous in nature (area $\mathrm{C}$ in Figure 5, indicating the ductile fracture presented in Figure 6d).

The fracture surfaces of the HCF LPBF TI6Al4V test specimens built in the X- and Y-directions were also analysed. These test specimens showed similar fracture surface features. Here the cracks were initiated at surface irregularities where the support structures had been removed from the specimens, and which acted as high stress concentration sites. Figure 7 shows the fracture surface of the Y10 specimen, which failed after 1002143 cycles at the maximum stress of $200 \mathrm{MPa}$. 


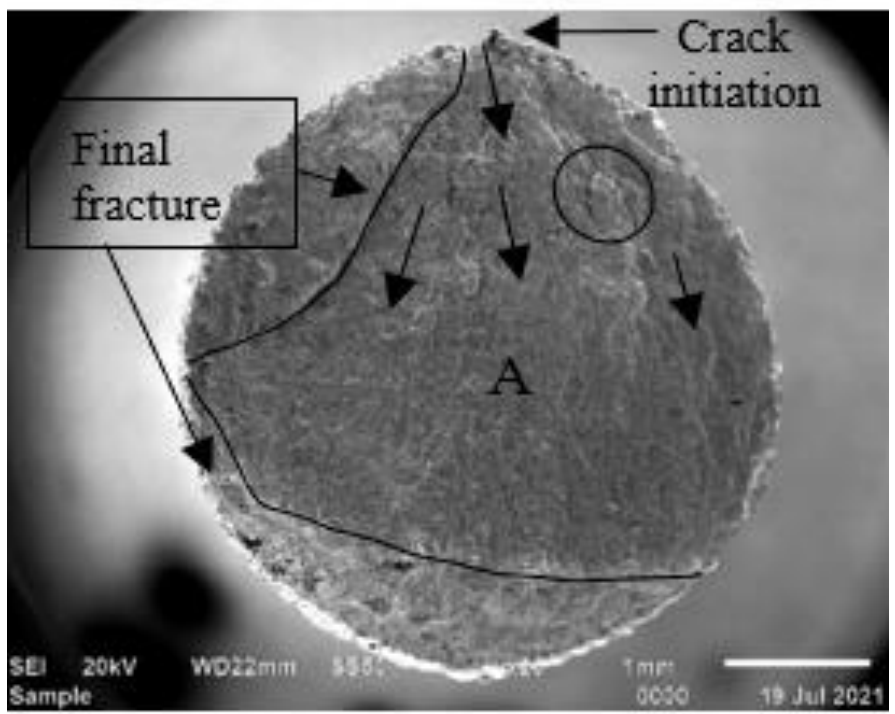

Figure 7: SEM SEI of fracture surface of $Y 10$ specimen

In the $\mathrm{Y} 10$ specimen, the crack was initiated at the surface. A high magnification of this crack initiation area is shown in Figure 8a. The crack propagated almost symmetrically down towards the centre of the specimen, as indicated by the arrows. Fatigue striations were observed in the slow propagation area (area $A$ in Figure 7). This area had fatigue striations below the initiation point.

Gong et al. [19] observed similar striations on their heat-treated TI6Al4V test specimens, and concluded that a transition from transgranular cleavage occurred and then changed to final fast fracture in ductile dimple mode. Micro-cracks were also observed in the encircled area in Figure 7, and appeared to be connected to the tear ridges in the stable crack propagation area. Striations were also observed in this area. A higher magnification of this area is shown in Figure 8c. The final fracture of the Y10 specimen in Figure 7 was similar to that of Z4 in Figure 5.

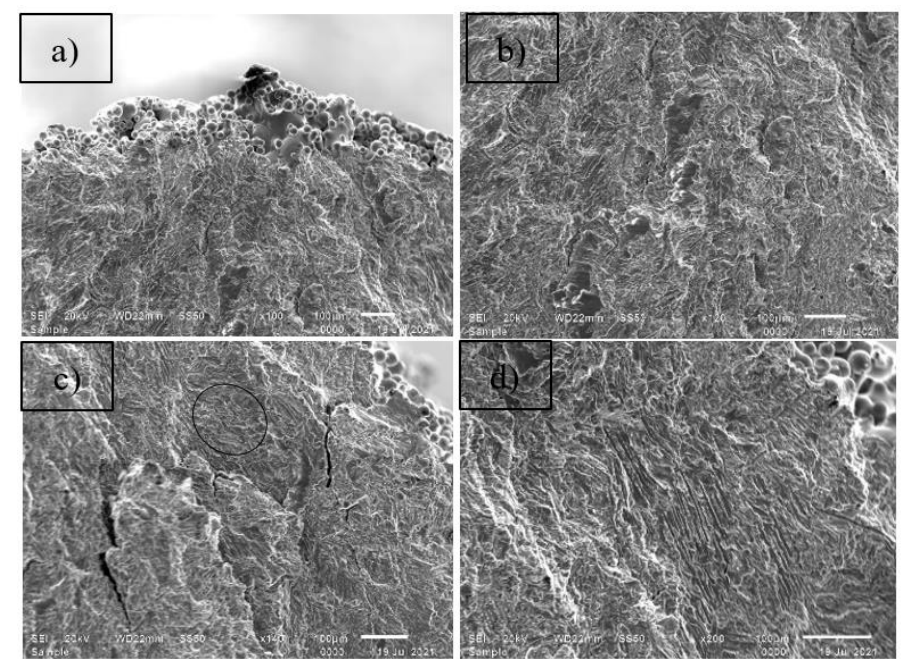

Figure 8: SEM SEI of high magnification areas of Figure 7: a) crack initiation with powder particles indicating lack of fusion; b) area A, showing slow crack propagation with fatigue striations; c) circled area in Figure 7, showing micro-void and striations; d) high magnification of Figure 8c on the striations (circled area).

A comparison of Figure $6 a$ with Figure $8 a$ showed that the number of cycles to failure was related to the area of stable crack propagation. Specimen Z4 had a smaller area of stable crack propagation than specimen Y10. The number of cycles to failure of specimen Y10 was much higher than that of Z4 (which failed at 50142 cycles, while Y10 failed at 1002143 cycles). This observation corresponds with the study of fracture 
features by Sachs et al. [20]. They observed that the size of the overload zone of the fracture surface indicated the magnitude of the load when the final fracture occurred. Malefane et al. [14] observed similar features in their machined HCF LPBF Ti6Al4V test specimens.

The crack initiation points of Z4 in Figure 5 and of Y10 in Figure 7 were different. In the Z4 specimen, crack initiation was the result of an inclusion near the sub-surface region that resulted in the specimen's shorter fatigue life. Chandran [21] discovered that inclusions can result in a much shorter fatigue life when they are located close to the sample surface in comparison with inclusions in the bulk of a part. Internal defects have been reported as the cause of failure in high-cycle fatigue [1, 3, 19, 20]. Wycisk et al. [6] suggested that this was the case only for specimens with a very short life - as observed in this study with the Z4 specimen, which had a shorter life because of an inclusion, while the specimens with longer lives had crack initiation arising on the surface.

\section{CONCLUSIONS}

This study confirmed that the inherent LPBF surface roughness had an impact on the HCF performance of Ti6Al4V(ELI) test specimens. This implies that surface finishing would be needed to improve the fatigue performance for applications such as structural aerospace components.

In addition, the support structures impacted negatively on the fatigue performance, even though they helped to maintain the integrity of the part during the LPBF process. This confirms that the design of a component should be done in such a way that the support structures are not placed on critical load-bearing areas, in order to avoid the creation of local stress concentration.

\section{ACKNOWLEDGEMENTS}

The financial support of the South African Department of Science and Innovation through the Collaborative Programme in Additive Manufacturing, Contract No. CSIR-NLC-CPAM-18-MOA-CUT-01, is gratefully acknowledged.

The assistance of the Centre for Rapid Prototyping and Manufacturing with the LPBF building of the test specimens is appreciated. The Product Development Technology Station assisted with the removal of the test specimens from the base plate, and their assistance is also acknowledged.

Necsa is acknowledged for assisting with the micro-CT analysis. The CSIR's mechanical testing laboratory team is acknowledged for assisting with the machining of the threads, as well as the tensile and fatigue testing of the specimens. The University of the Free State is also acknowledged for allowing the use of the SEM in their Geology Laboratory.

[1] K. Karolewska, B. Ligaj, M. Wirwicki, and G. Szala, "Strength analysis of Ti6Al4V titanium alloy produced by the use of additive manufacturing method under static load conditions," J. Mater. Res. Technol., vol. 9, no. 2, pp. 1365-1379, 2020.

[2] S. Liu and Y. C. Shin, “Additive manufacturing of Ti6Al4V alloy: A review," Mater. Des., vol. 164, $107552,2019$.

[3] S. M. Yusuf, S. Cutler, and N. Gao, "Review: The impact of metal additive manufacturing on the aerospace industry," Metals (Basel), vol. 9, no. 12, p. 1286, 2019.

[4] P. Li, D. H. Warner, A. Fatemi, and N. Phan, "On the fatigue performance of additively manufactured Ti-6Al-4V to enable rapid qualification for aerospace applications," presented at 57th AIAA/ASCE/AHS/ASC Struct. Struct. Dyn. Mater. Conf., San Diego, California,USA, 2016.

[5] C. Cui, B. M. Hu, L. Zhao, and S. Liu, "Titanium alloy production technology, market prospects and industry development," Mater. Des., vol. 32, no. 3, pp. 1684-1691, 2011.

[6] E. Wycisk, A. Solbach, S. Siddique, D. Herzog, and F. Walther, "Effects of defects in laser additive manufactured Ti-6Al-4V on fatigue properties,” Phys. Procedia, vol. 56, pp. 371-378, 2014.

[7] G. Nicoletto, "A novel test method for the fatigue characterization of metal powder bed fused alloys," Procedia Struct. Integr., vol. 7, pp. 67-74, 2017.

[8] N. Sanaei and A. Fatemi, "Analysis of the effect of surface roughness on fatigue performance of powder bed fusion additive manufactured metals," Theor. Appl. Fract. Mech., vol. 108, p. 102638, 2020.

[9] X. Gong, T. Anderson, and K. Chou, "Review on powder-based electron beam additive manufacturing technology," Manufacturing Rev, vol.1, no. 2, p. 12, 2014.

[10] G. Nicoletto, R. Konečná, L. Kunz, and M. Frkáň, “Influence of as-built surface on fatigue strength and notch sensitivity of Ti6Al4V alloy produced by DMLS," in MATEC Web Conf., vol. 165, pp. 2-7, Poitiers, France, 2018. 
[11] M. Kahlin, H. Ansell, and J. J. Moverare, "Fatigue behaviour of notched additive manufactured Ti6Al4V with asbuilt surfaces," Int. J. Fatigue, vol. 101, no.1, pp. 51-60, 2017.

[12] ASTM E466-15, "Standard practice for conducting force controlled constant amplitude axial fatigue tests of metallic materials," ASTM International, West Conshohocken,PA, 2015.

[13] ASTM F3001-14, "Standard specification for additive manufacturing Titanium-6 Aluminum-4 Vanadium ELI (extra low interstitial) with powder bed fusion,"ASTM International, West Conshohocken,PA, 2021.

[14] L. B. Malefane, W. du Preez, and M. Maringa, "High cycle fatigue properties of as-built Ti6Al4V (Eli) produced by direct metal laser sintering," South African J. Ind. Eng., vol. 28, no. 3, pp. 1-12, 2017.

[15] T. Bhardwaj and M. Shukla, "Direct metal laser sintering of maraging steel: Effect of building orientation on surface roughness and microhardness," Mater. Today: Proc., vol. 5, no. 9, pp. 20485-20491, 2018.

[16] G. Casalino, S. L. Campanelli, N. Contuzzi, and A. D. Ludovico, "Experimental investigation and statistical optimisation of the selective laser melting process of a maraging steel," Opt. Laser Technol., vol. 65, pp. 151-158, 2015.

[17] V. Chastand, P. Quaegebeur, W. Maia, and E. Charkaluk, "Comparative study of fatigue properties of Ti-6Al-4V specimens built by electron beam melting (EBM) and selective laser melting (SLM)," Mater. Charact., vol. 143, pp. 76-81, 2018.

[18] M. Dallago, V. Fontanari, E. Torresani, M. Leoni, C. Pederzolli, C. Potrich, and M. Benedetti, "Fatigue and biological properties of Ti-6Al-4V ELI cellular structures with variously arranged cubic cells made by selective laser melting," J. Mech. Behav. Biomed. Mater., vol. 78, pp. 381-394, 2018.

[19] H. Gong, K. Rafi, T. Starr, and B. Stucker, "Effect of defects on fatigue tests of as-built TI-6AL-4V parts fabricated by selective laser melting," presented at SFF Symposium, Thompson Conference Center, Texas, USA, 2012.

[20] W. Neville and P. E Sachs, "Fracture features," J. Fatigue Anal. Prev., vol. 5, no. 2, pp. 11-15, 2005.

[21] K. S. R. Chandran, "Duality of fatigue failures of materials caused by Poisson defect statistics of competing failure modes," Nat. Mater., vol. 4, pp. 303-308, 2005. 